4. Зубарева К.В., Бадуртдинов А.А., Васильев А.М. Насилие в семье как основной показатель при квалификации // Международный научно-исследовательский журнал. 2020. № 6-4 (96). С. 137-141.

5. $\quad$ Тольятин П.Д. Уголовное право и наказание. М., 2018. С.78.

6. Tileubergenov Y., Pelevina N., Taubaev B., Vasiliev A. The role of social memory in reconstruction of the historical past. social memory and historical past // Astra Salvensis. 2018. T. 6. № 12. С. 67-72.

7. Васильев А.М., Окружко В.Ю. Особенности криминологической характеристики личности террориста // Юридическая наука. 2019. № 9. С. 58-61.

\title{
Ляпустина Н.А. \\ Существенные условия договора строительного подряда: теория и практика
}

Владивостокский государственный университет экономики и сервиса

(Россия, Владивосток)

doi: $10.18411 / l j-06-2021-225$

\section{Аннотация}

Статья посвящена актуальной не только для исследователей, но и для правоприменителей теме - выявлению существенных условий договора строительного подряда. Основываясь на дефиниции договора строительного подряда, научных исследованиях и сложившейся судебной практики в данной области, автор делает вывод о том, какие условия следует считать существенными для данного договора.

Ключевые слова: существенные условия, договор строительного подряда, юридическая литература, судебная практика.

\section{Abstract}

This article focuses on the actual not only for researchers, but also for law enforcement - identifying the essential terms of a construction contract. Based on the definition of a construction contract, research and established judicial practice in this area, the author concludes what conditions should be considered essential for this contract.

Keywords: essential conditions, construction contract, legal literature, court practice.

На сегодняшний день договор строительного подряда является, пожалуй, наиболее распространённым видом договора подряда. Необходимость строить новые здания, реконструировать, ремонтировать и проводить другие работы с уже существующим объектом, обуславливает важность регулирования данных отношений. Однако законодательство не лишено недостатков, в частности и в положениях, касающихся строительной сферы.

В свете принципиальной значимости отношений, вытекающих из рассматриваемого договора, важно понимать, какие условия являются существенными для данного вида договора, какие тенденции складывается на практике при разрешении данного вопроса. В особенности это имеет наибольшее значение для правоприменителя при разработке проекта договора, чтобы уже на данном этапе учесть возможные перспективы и риски и выработать выгодные условия, минимизирующие шансы возникновения спорных ситуаций.

Вначале необходимо понять, что собой представляет данный договор и, основываясь на определении, установить, какие его условия являются существенными. «Договор строительного подряда представляет собой соглашение, в силу которого подрядчик обязуется в установленный договором срок построить по заданию заказчика определенный объект либо выполнить иные строительные работы, а заказчик обязуется создать подрядчику необходимые условия для выполнения работ, принять их результат и уплатить обусловленную цену» [1].

Из определения видно, что существенными условиями для данного договора являются предмет, цена и срок. Однако совпадает ли такой подход с мнениями 
исследователей и сложившейся судебной практикой, и с какими проблемами может столкнуться правоприменитель, определяя содержание некоторых условий, попробуем выяснить.

Неоспоримо, что в любом договоре предмет является существенным условием. Однако, несмотря на законодательное закрепление положения о предмете, формулировка о нём не достаточно чёткая. Как следствие возникают споры и в науке, и на практике по поводу того, что должно считаться предметом договора строительного подряда.

Законодательно установлено, что «договор строительного подряда заключается на строительство или реконструкцию предприятия, здания (в том числе жилого дома), сооружения или иного объекта, а также на выполнение монтажных, пусконаладочных и иных неразрывно связанных со строящимся объектом работ» [2].

К сожалению, в юридической литературе нет единообразия в определении предмета рассматриваемого договора. Среди исследователей сложилось два основных подхода к определению предмета данного договора. Первый предполагает, что предмет - это работа и ее овеществленный результат, а второй - только результат работы.

Приверженцы первой позиции считают, что, так как для достижения результата подрядчик обязательно должен совершать действия, составляющие сущность работы, предметом договора являются работа и результат.

Ряд учёных не соглашается с такой позицией и придерживается точки зрения, что предметом данного договора является законченный результат [3].

Однако представляется, что обе позиции неверные. Исходя из формулировки п. 2 ст. 740 Гражданского кодекса РФ, предметом договора строительного подряда всё же являются работы по строительству и реконструкции объектов капитального строительства и другие работы неразрывно связанные со строящимся объектом, а не результат этих работ. Справедливо будет отметить, что подрядчик несёт обязанность по передаче результата работ заказчику, но сам договор заключается по поводу выполнения работ подрядчиком по заданию заказчика.

Помимо создания новых, реконструкции существующих объектов, а также ремонтных работ, рассматриваемый договор может быть заключён для выполнения сноса, демонтажа объекта. Например, в такой специфической индустрии, как атомная энергетика, существует строительные проекты как по созданию, монтажу объектов, так и проекты по их ликвидации. Последние предусматривают особые технологические операции, которые позволяют безопасно вывести соответствующий объект из эксплуатации.

Также кроме выполнения работ по созданию, реконструкции, ремонту и демонтажу объекта капитального строительства стороны могут предусмотреть в договоре обязанность подрядчика осуществлять техническую эксплуатацию объекта, который он построил, то есть осуществлять обслуживание, плановые мероприятия по его ремонту, осмотру, проверке функционирования. Такой договор считается разновидностью договора строительного подряда. Однако техническая эксплуатация то есть обслуживание, больше относиться к категории услуг, чем к работе. В этом случае договор похож на смешанный, который включает элементы двух договоров строительного подряда и возмездного оказания услуг.

Не менее значимым элементом для данного договора является цена. Как следует из определения, условие о цене является существенным, значит, стороны обязательно должны о нём договориться. В науке не часто можно встретить исследователей, не разделяющих подход, что условия о цене для данного договора являются существенными. Однако некоторые всё же не придерживаются такого мнения. Так, Харунова И.Н. определяет как существенные условия только предмет и срок [4, с. 574]. Ляхова М.В. также указывает на то, что условия о цене для данного договора в настоящее время уже не считаются существенными [5, с. 6]. 
Исходя из анализа судебной практики, сомнений по поводу того, что цена договора строительного подряда - существенное условие, не возникает. Так, постановлением Арбитражного суда Московского округа от 14.10.2014 N Ф05-11591/14 по делу N A40-184717/13 оставлены без изменения решения первой и апелляционной инстанции по делу N A40-184717/13 о незаключённости договора в связи с отсутствием достижения согласия сторон по существенным условиям, в частности по цене.

Ещё одним условием, без которого рассматриваемый договор считается незаключённым, является условие о сроке. Так, апелляционным определением Ленинградского областного суда от 21.06.2017 N 33-3691/2017 по делу N 2-239/2017 договор строительного подряда был признан незаключённым, в связи с тем, что стороны договорились не обо всех существенных условиях, в том числе о сроке (отсутствовали графики производства работ). Аналогичный вывод сделан в постановлении Арбитражного суда Московского округа от 17.08.2015 N Ф05-7024/2014 по делу N A40-14258/13, постановлении Арбитражного суда Московского округа от 01.02.2016 N Ф05-21007/2015 по делу N А40-48559/2015. Этот подход представляется более верным и вытекает из п. 1 ст. 740 Гражданского кодекса РФ, который прямо указывает на то, что в договоре должен устанавливаться срок.

Подводя итоги исследования, можно прийти к выводу, что, несмотря на порой неоднозначное мнение, сложившееся в юридической литературе, в судебной практике сформировалась позиция, что договор должен считаться незаключённым, если стороны не договорились о его предмете, цене и сроке. Следовательно, судами признаются эти условия как существенные.

По поводу того, что признаётся предметом договора строительного подряда, также возникает немало разногласий. Однако на основании положений Гражданского кодекса РФ, предметом по данному договору следует признавать строительные работы, указанные в п. 2 ст. 740 ГК РФ.

\section{$* * *$}

1. Гражданское право: Учебник. В 2 т. / Под ред. Б.М. Гонгало. Т. 2. - 2-е изд., перераб. и доп. - М.: Статут, - 2017. - С. 543.

2. "Гражданский кодекс Российской Федерации (часть вторая)" от 26.01.1996 N 14-Ф3 (ред. от 09.03.2021) // СПС «КонсультантПлюс». http://www.consultant.ru/document/cons_doc_LAW_9027/\#dst0

3. Подолянюк А.О. Проблема определения предмета договора строительного подряда - Текст: электронный / А.О. Подолянюк // Материалы Всероссийской заочной научно-практической конференции «Современные проблемы гражданского права: итоги работы кружка по гражданскому праву "Цивилисть" им. С.А. Муромцева» - Краснодар: Кубанский государственный университет. - 2017. - C. 65-70 - URL: https://www.elibrary.ru/item.asp?id=36463834

4. Харунова И.Н. Существенные условия договора строительного подряда, содержание и трактовка судами отдельных вопросов - Текст: электронный / И.Н. Харунова // Вестник современных исследований - Омск: ИП Соловьёв В.А. - 2018. - 5.4 (20). - С. 574-577 - URL: https://www.elibrary.ru/item.asp?id=36463834

5. Ляхова М. В. Проблемы регулирования отношений по договору строительного подряда - Текст: электронный / М. В. Ляхова // Юридический факт - Кемерово: ИП Никитин И.А. - 2019. - 59. - С. 6-8 - URL: https://elibrary.ru/item.asp?id=39864030

\section{Мазур A.B. \\ Страхование строительно-монтажных рисков}

ФГАОУ ВО «Дальневосточный федеральный университет» (Россия, Владивосток)

doi: $10.18411 / l j-06-2021-226$

\section{Аннотация}

В статье рассматриваются проблемы по страхованию объектов комплексного договора страхования строительно-монтажных рисков на основании федерального законодательства. Данная проблематика не относится к числу достаточно изученных. В 